\title{
Explaining Croatia's Accession to and Compliance with WTO, from a Constructivism Approach
}

\author{
Xinting Liu ${ }^{1, *, \dagger}$ Yihang Liu ${ }^{2, *, \dagger}$ Jingyi Wang ${ }^{3, *, \dagger}$ Weiyi Xing ${ }^{4, *, \dagger}$ \\ ${ }^{1}$ Faculty of European Languages \& Cultures, Guangdong University of Foreign Studies, Guangzhou, Guangdong, \\ China \\ ${ }^{2}$ Heavener School of Business, University of Florida, Gainesville, Florida, United States \\ ${ }^{3}$ School of Translation, Jinan University, Guangzhou, Guangdong, China \\ ${ }^{4}$ School of International Relations, Beijing Foreign Studies University, Beijing, China \\ *Corresponding author.Email: 120201905060@gdufs.edu.cn, ${ }^{*}$ liuyihang@ufl.edu, ${ }^{3}$ gabriella@stu2019.jnu.edu.cn,
}

${ }^{4} 18160065 @ b f s u . e d u . c n$

These authors contributed equally.

\begin{abstract}
As a country divorced from Yugoslavia and would like to become a democratic country, Croatia is unique in its foreign policy, especially its measures and attitude to deal with the international institutions. Sometimes its attitude is known as positive but limp. This work is aimed to explain this. We did many empirical researches to examine why Croatia always compel to WTO rules and why it made so many compromises in the process of joining it. These researches adopt three researching methods, including the behavioral approach, concept analysis, and comparative studies between different theories. Then, we decided to use constructivism theory to explain Croatia's practice. And we find that it is the consensus and the interests of advocating them that drive Croatia to obey WTO norms and regulations. Croatia has a deep understanding of its values and WTO's shared values and the way to connect them, so this is also another factor. In this article, we also make some prospects of Croatia, and we can see that there will be more cooperation rather than contradictions in the future. Croatia will be a surrender and an advocate of international rules instead of a defector. In the end, we conclude that examining Croatia's behavior should consider a wide range of social and historical factors. Even we should notice the necessity and the interests of upholding norms and consensus. It is not only a competition of power.
\end{abstract}

Keywords: Croatia, Accession, Compliance, Constructivism.

\section{INTRODUCTION}

As a former socialist country and a Yugoslav member state, Croatia has made great efforts to join the WTO after independence. Why was Croatia so eager to become a member of the WTO? What benefits could such a decision bring to Croatia at that time? At present, the relevant literature on the motivation of Croatia's entry into WTO is very rare, and this research field seems to be blank. Other Yugoslav member states have not shown such a strong desire to join the WTO and accelerate the reform of the economic system as Croatia. This phenomenon makes Croatia so different from other Eastern European countries. Therefore, the causes of Croatia's attitude towards WTO are worth studying. In this essay, we aim to study why Croatia abided by WTO rules and why it made so many compromises in the process of joining the WTO.

From 1993 to 2000, Croatia made many changes and efforts in seven years to obtain the qualification to join the WTO. On the one hand, we should emphasize that all EU countries have joined the WTO, so joining the WTO also played a positive role in promoting EU membership. Then the reason why Croatia wanted to join the EU could be related to its desire to join the WTO. We tried to find the reason in some studies on the national situation of Croatia at that time. According to $\mathrm{Hu}$, the first president Tudjman after Croatia's independence and the later Croatian government was close to Europe [1]. Croatia has been trying to get closer to the western world. Moreover, 
in terms of the category of civilization, Croatia belongs to European civilization. Zuo also argued that the main religion in Croatia is Catholicism $(76.6 \%$ of the total population) [2]. Around $800 \mathrm{AD}$, the Croats accepted Christianity from the patriarchal Frankish empire [2]. After Christianity split into Catholicism and Orthodox Church in 1054 (Protestantism split again in the 16th century), Croats converted to Catholicism [2]. Western civilizations are Catholicism and Protestantism, and their core values. The Christian culture of more than 2000 years is still the spiritual bond of Europeans. Therefore, from the perspective of identity, Croatia's desire to join the WTO can be explained.

On the other hand, another point we need to pay attention to is the damage to the economy caused by the war triggered by Croatia's independence. According to Zuo, in 1990, Croatia began to implement a multi-party parliamentary system politically and a market economic system economically [3]. However, due to the war and complex ethnic contradictions caused by Croatia's independence, its economic transition process has been affected to a certain extent [3]. The war triggered by Croatia's independence caused damage to the economy. According to Zhu, in the early stage of independence, Croatia spent huge financial resources on the establishment of the army and the purchase of arms, resulting in a significant decline in the living standards of residents, the wage income of ordinary residents was difficult to maintain their daily life, and the decline in purchasing power made it difficult for economic transformation [4]. After the war of independence, Croatia's investment environment deteriorated because of the high risk of war, and many foreign investors were unwilling to invest in Croatia [4]. Accession to the WTO could become a driving force for China and Croatia to develop the economy and realize economic transformation.

In addition, in this paper, we not only study why Croatia joined Croatia. We also focused our research on how Croatia abided by WTO rules after it acceded to the WTO. Therefore, we chose a trading dispute between Croatia and Hungary in 2003. We want to know why Croatia still abided by WTO rules when Croatia's interests were threatened.

This article on the WTO compliance of Croatia will take a different perspective from previous studies. We no longer take a realistic view and focus only on Croatia's national interests. If the reason for the WTO compliance of Croatia is interesting, it is impossible to explain why Croatia would not hesitate to damage its interests to obey the rules of the WTO after it accedes to the WTO. Therefore, we choose to use constructivism to analyze Croatia's behavior. We will focus on the relationship between identity and interests and the internalization of the rules into actors.
This article will be divided into four parts. Firstly, the relevant theories of constructivism will be introduced in detail. In the second part, the behavior of the WTO compliance of Croatia will be divided into two parts for discussion before and after China's accession to the WTO, and the reasons for Croatia's behavior will be analyzed from the perspective of constructivism. A trading dispute between Croatia and Hungary will be explained and discussed in the third part. Finally, we will discuss the prospect of Croatia from the perspective of constructivism.

\section{THE CONSTRUCTIVIST THEORY}

In international relations, constructivism is a social theory that asserts that significant aspects of international relations are shaped by ideational factors (which are historically and socially constructed), not simply material factors [5]. Compared to some other prominent IR approaches and theories, constructivists see the identities and interests of actors as socially constructed and variable, and their identity is not immutable and cannot be assumed externally $[6,7]$.

Similar to rational choice, constructivism does not make specific predictions about international relations [8]. This is a way to study international politics, not a substantive theory of international politics.

Constructivism primarily seeks to demonstrate how core aspects of international relations are, contrary to the assumptions of neorealism and neoliberalism, socially constructed. This means that ongoing social practices and interactive processes give their form. Alexander Wendt claimed two increasingly accepted basic tenets of Constructivism "that the structures of human association are determined primarily by shared ideas rather than material forces, and that the identities and interests of purposive actors are constructed by these shared ideas rather than given by nature.[9]". This is not to say that constructivists believe that international politics is "ideas all the way down", but international politics has both material and conceptual factors. Constructivist research focuses both on causal explanations for phenomena and analyses of how things are constituted [10]. In the study of national security, Emphasis is placed on the constraints of culture and identity on security policies and related behavior. Identity is necessary to ensure at least some degree of predictability and order. The object of constructivist discourse can be regarded as the arrival of the recent debate on the ontological status of epistemology, sociology of knowledge, agent/structure, and social facts, which is a basic factor in international relations.

The notion that international relations are affected by power politics and ideas is shared by writers who describe themselves as constructivist theorists [11]. According to this view, the fundamental structures of 
international politics are social rather than strictly material. This leads social constructivists to argue that changes in the nature of social interaction between states can bring a fundamental shift towards greater international security [12].

Central to constructivism are the notions that ideas matter and that agents are socially constructed rather than given [7]. In contrast to other mainstream international relations approaches, constructivists often conceive of agents as a dependent variable.

We chose constructivism to study Croatia because, during our studying procession, we found that while Croatia decided to join the WTO, it was affected by its identity in Europe and its value cognition. From the perspective of constructivism, it is more appropriate and clearer to analyze the state behavior of Croatia.

\section{THE WTO COMPLIANCE OF CROATIA}

Why does Croatia comply with WTO rules? In this part, we will discuss it in two parts. First, before joining the WTO, Croatia wanted to join the WTO. The second is why Croatia always abides by the rules of the WTO after it accedes to the WTO.

\subsection{Croatia's Accession to WTO}

From 1993 to 2000, Croatia has made many changes and efforts to obtain the qualification to join the WTO. First, from the perspective of interests, Croatia's economic difficulties have seriously hindered Croatia's economic transformation. According to Zhu, in the early 1950s, the former Yugoslavia took the lead in implementing reform in socialist countries, and the economy developed significantly [1]. After the mid1960s, the autonomous economic system began to expose fatal weaknesses, and in the 1970s, the economic development lingered, and in the 1980s, the economy deteriorated and fell into a comprehensive crisis [13]. According to Zhu, Croatia's GDP decreased by $40.5 \%$ from 1989 to 1993 [13]. However, accession to the WTO will contribute to Croatia's economic transformation and promote economic development.

Moreover, Croatia hoped to become a true democracy. The former Yugoslavia is famous for its socialist autonomy system based on social ownership and the corresponding autonomous social planning system. After 30 years of practice, it has been proved that this autonomous economic system was unsuccessful. In the transition from the autonomous economic system to the market economic system, the most important thing was to transform the ownership structure and cultivate the market system. According to He, Croatia has ended its socialist system, so it hoped to quickly change its economic and political system and become a democratic country that would eventually integrate with the international community [14]. Croatia used the conditions of its accession to the WTO to put pressure on domestic opposition to reform, promote domestic economic reform, completely change the previous concept and habit of planned economy, and finally become a real democratic country.

Finally, Croatia considers itself a European country, and its culture is similar to that of Europe. From the perspective of history and culture, although Croatia is a Slavic nation in the Balkans, it has been ruled by Austria and Hungary for a long time. In history, Croatia was once a part of the Austro-Hungarian Empire. According to $\mathrm{Hu}$, since the 15 th century, Italy has also greatly impacted Croatia's traditional culture and customs [15]. More importantly, the Croats followed Christianity as early as 1000 years ago, so they were returned to "Slavic Catholic Central Europe" by some Western European scholars [15]. Therefore, Croatia belongs to European civilization, while other Western Balkan countries are more affected by Byzantine and Islamic civilization. According to He, Croatia hoped to strengthen its relations with the EU because Croatia considered itself a part of Europe and wanted to join the EU, so it has made efforts in human rights, media democratization [14]. For Croatia, accession to the WTO can promote Croatia's accession to the EU, which can also be regarded as a choice made by Croatia as part of Europe.

Therefore, when we analyze the motivation of Croatia's accession to the WTO from the perspective of constructivism, we can find that Croatia's behavior is affected by identity and interests. According to Wendt, "Interest refers to the needs of actors, and interest presupposes identity" [16]. Since Croatia considers itself part of Europe and wants to become a democracy, Croatia will make the same choices as democracies and EU Member States. In this case, the interests of a democratic country and EU Member States will be related to accession to the WTO. Therefore, Croatia has also made this choice.

\subsection{Trade Policy}

After joining the WTO, Croatia has also made efforts in foreign trade policy. According to the WTO report, since it acceded to the WTO in 2000, Croatia has carried out important reforms in trade and investment and reduced its simple average manganese tariff from $12.1 \%$ in 2000 to $7.1 \%$ in 2009 [17]. In addition, according to WTO data, Croatia participated in the central European Free Trade Agreement (CEFTA 2006) with seven other parties; Signed free trade agreements with four European Free Trade Association (EFTA) countries; And signed a bilateral free trade agreement with Turkey [17]. In 2008, Croatia's preferential trade with its 39 partners totaled US $\$ 34.448$ billion (accounting for $76.9 \%$ of Croatia's total trade), of which $82.2 \%$ came from the EU, $14.2 \%$ from CEFTA in 2006, 2\% from the European Free Trade Agreement and $1.6 \%$ with Turkey [17]. These data show 
Croatia's changes and efforts in foreign trade since it acceded to the WTO. They proved that after Croatia's accession to the WTO, it always abided by the rules of the WTO after its accession to the WTO.

From the perspective of constructivism, we analyze the behavior of Croatia after its accession to the WTO. According to Ferimo, "The international community's rules, institutions, and values are internalized into actors. They are not only limited state behavior but also change national preferences [18]." After joining the WTO, Croatia has complied with WTO norms and worked hard to become a better WTO member. The reason for this behavior is that Croatia, as a member of WTO, has shared WTO rules and values and has classified them as its own identity. WTO restricted Croatia's behavior and promoted Croatia's trade reform, and changed Croatia's view of abiding by WTO rules.

\section{EXPLANATIONS AND EVIDENCE FOR THE COMPLIANCE}

\subsection{How Constructivism Explains}

We also use constructivism to explain why Croatia obeys these norms and regulations. And we think that there are three main points.

\subsubsection{The Power of the IOs}

Constructivism denies that the international community is in a state of anarchy [19]. Institutions can be understood as global governments with power because their decisions are rational, moral, and legal. They grasp and control a wide range of data, information, and knowledge. So, in this theory, WTO is an authority higher than Croatia. Croatia has to submit to it. If Croatia betrays WTO rules, this will cause damage to Croatia directly.

\subsubsection{Necessity of Compliance}

The next point is that international institutions are founded upon the consensus [20]. If Croatia betrays the regulations, it just means that it betrays the consensus of the international community. Furthermore, it means that it set itself against most of the countries. This causes isolation. It is very dangerous, especially to small countries like Croatia. It is deadly harmful to Croatia's reputation and further development.

\subsubsection{Gains of the Compliance}

Thirdly, the consensus not only creates institutions but also shapes the countries themselves [21] and shapes some particular interests in today's international politics. In this interlinked world, institutional rules are increasingly received, so many international consensus and institution norms are highly relevant to countries' interests. Croatia can gain a lot of it follows these common-received rules. Obeying them is highly beneficial to Croatia's interests, especially long-term interests.

Last but not least, being an advocate of the norms and consensus can help a country have a say on international affairs, also known as discourse power, can help it earn more respect and influence. This is very beneficial to small countries like Croatia because they tend to participate more in global affairs, and of course, more beneficial than violating rules.

\subsection{An Evidence}

Now let me introduce evidence to prove our arguments; it is about a trading dispute between Croatia and Hungary in 2003 [22].

Croatia prohibited ruminants and other animals that have economic significance, such as pigs, fish, etc. And it was claimed that these measures were taken to prevent the spread of a certain disease.

Hungary suffered a great loss because of this. Then he brought this case to the WTO and claimed that Croatia's measures are groundless and are not based on any scientific principle.

But then, the two countries solved the problem through an efficient negotiation. In the same year, after settling the problem, Croatia swiftly canceled some bans on many controversial animals in 2003. This reflects that Croatia does not want to violate WTO rules openly, does not want to betray consensus after being uncovered, and prefers to obey them.

\section{FUTURE PROROSPECT OF CROTIA}

\subsection{General Prospect}

In international relations, Croatia, as a small country in Europe that has just become independent, cannot compete with some big countries in the region. Therefore, Neo-liberalism has limited explanatory power to help us to understand the compliance of Croatia. Constructivism has stronger explanatory power than neo-liberalism to prove our perspective. Based on the theory of Constructivism, Croatia has a high probability of continuing to clarify its relations and interests with other countries following its European identity. From this point of view, Croatia will continue to abide by WTO rules and regulations to seek continued development capabilities. Over time, compliance with the rules and regulations of the WTO and other organizations in the world will become a basic consensus as it passes on from generation to generation. Croatia will also develop steadily within this framework. But despite this, Croatia still lacks the conditions to become a regional power. In a sense, this is also a kind of sorrow for a small country. 


\subsection{The Economic Impact and Prospects of Croatia after Entering WTO}

Before 2000, Croatia's economy had not changed much. However, when Croatia joined WTO in 2000, due to changes in its economic policy and structure and the good momentum of international economic development, its GDP rose from 20 billion USD in 2000 to 70 billion USD in 2008 [23]. After the 2008 financial crisis, all economies in the world suffered a recession, and Croatia was not immune. Since 2015, its economy has begun to recover again. Due to the transformation of the economic structure, the service industry, dominated by tourism, is the most important economic industry in Croatia. This also shows that the Croatian economy has been fully globalized. This also makes its economic conditions largely dependent on global economic conditions. From the perspective of outlook, as a small regional country, Croatia cannot change the international economic situation, so its economic autonomy is very small. But as long as the international economy can maintain a good trend, the Croatian economy will also develop. Croatia will join the Eurozone in 2023, which is another opportunity for its economic growth.

\subsection{The Impact and Prospects of Croatian People's Livelihood after Entering WTO}

Croatia used to be an economically more developed region in Yugoslavia than other regions, so its people's livelihood has always maintained a relatively high level. This includes food, education, transportation, and other factors. But despite this, its living standards and per capita GDP are still far behind Western European countries. After Croatia joined the WTO, with the opening of the market, people's living standards have rapidly improved under economic development. GNI per capita has also changed from 5,000 USD before joining WTO to 15,000 USD now [24]. At the same time, the poverty rate in Croatia has also fallen sharply [25]. With the development of the economy, Croatia will maintain a relatively high level of people's livelihood in the future, although it is unlikely to be compared with developed countries in Western Europe in a short time.

\section{CONCLUSION}

In conclusion, we have applied constructivist theory to explain Croatia's accession and compliance with WTO. We found out that the driving force of Croatia's compliance is its European identity and the relationship between identity and interests, and the internalization of the rules into actors. At the same time, we have made a good explanation of the reasons why Croatia abides by WTO rules in terms of rule-making, international consensus, gaining benefits, and the right to speak internationally, and we use Hungary's case as the evidence to prove that Croatia is willing to follow WTO rules in order to obtain longer-term benefits. Therefore, we finally concluded that Croatia would abide by WTO rules and comply with the rules as a basic consensus over time.

The most important factor of constructivism in international relations is based on factors such as historical and social, rather than simply a comparison of strengths. This is very effective for studying the foreign policy of a small country like Croatia because, in joining the WTO, Croatia's value and sense of identity as a European country played a decisive role.

\section{REFERENCES}

[1] Yong $\mathrm{Hu}$ (2015). "European dream" and "Europeanization": Croatia's accession to the EU and its impact. International Forum, 017 (006), 2530.

[2] Ya Zuo (2006). Croatia and European integration. European studies, 024 (004), 27-38.

[3] Ya Zuo (2007), Croatia, social sciences literature press.

[4] Xingqiao Zhu(1996). Current situation and existing problems of Croatia's economic transition. World economy, 000 (011), 26-27

[5] Finnemore, Martha; Sikkink, Kathryn, 2001, "Taking Stock: The Constructivist Research Program in International Relations and Comparative Politics". Annual Review of Political Science. 4 (1): P391-416.

[6] Barnett, Michael L., 2018, Gheciu, Alexandra; Wohlforth, William C (eds.). "Constructivism". The Oxford Handbook of International Security. P85-99

[7] Wendt, Alexander, 1999, Social Theory of International Politics. Cambridge University Press. P1-4

[8] Fearon, James; Wendt, Alexander, 2002, "Rationalism v. Constructivism: A Skeptical View", Handbook of International Relations, SAGE, P5272

[9] Hopf, Ted, 1998, "The Promise of Constructivism in International Relations Theory". InternationalSecurity. 23 (1): P171-200.

[10] Katzenstein, Peter J. Keohane, Robert Owen, Krasner, Stephen D., 2002, Exploration and contestation in the study of world politics.

[11] Baylis, John, 2011, The Globalization of World Politics. Oxford University Press Inc. P237

[12] Alexander Wendt, 1999, Social Theory of International Politics. Cambridge: Cambridge University Press, P8-15 
[13] Zhu Xingqiao (1996). Current situation and existing problems of Croatia's economic transition. World economy, 000 (011), 26-27

[14] Gang He (2015). Autobiographical narration and the power of identity evolution: a comparative study on the Europeanization process of Croatia and Serbia (Doctoral discourse, School of Foreign Affairs)

[15] Yong $\mathrm{Hu}$ (2015). "European dream" and "Europeanization": Croatia's accession to the EU and its impact. International Forum, 017 (006), 2530 .

[16] Alexander Wendt (1999). Social Theory of International Politics. Cambridge: Cambridge University Press, 1999: p.1

[17] World Trade Organization (2010), Trade policy review - Croatia 2010, available from: https: //www.wto.org/

[18] Martha Ferrimo (2001), National Interests in the International Community.

[19] Ted Hopf, 1998. The promise of constructivism in international relations theory. Retrieved from: International security (1998) 23 Page174
[20] Qirong Zheng, Guihong Zhang, Shuangwu Yan, 2018. International Institutions. Retrieved from: Page 48

[21] Alexander winter, 2000. Social theory of international politics.

[22] WTO, 2003. Croatia - Measures Affecting Imports of Live Animals and Meat Products. Retrieved from: https:

//www.wto.org/english/tratop_e/dispu_e/cases_e/ds 297_e.htm

[23] The World Bank, 2020. GDP (current \$US) - Croatia. Retrieved from: https: //data.worldbank.org/indicator/NY.GDP.MKTP.CD ?locations $=\mathrm{HR}$

[24] The World Bank, 2020. GNI per capita, Atlas method (current US\$) - Croatia. Retrieved from: https:

//data.worldbank.org/indicator/NY.GNP.PCAP.CD ?locations $=\mathrm{HR}$

[25] The World Bank, 2020. Poverty headcount ratio at national poverty lines (\% of population) - Croatia. Retrieved from: https: //data.worldbank.org/indicator/SI.POV.NAHC?loca tions $=\mathrm{HR}$ 